Research Article

Ariadni Polychroniou*

\title{
Towards a Critical Reconstruction of Modern Refugee Subjectivity: Overcoming the Threat-Victim Bipolarity with Judith Butler and Giorgio Agamben
}

https://doi.org/10.1515/opphil-2020-0185

received May 11, 2021; accepted September 29, 2021

Abstract: The accurate illustration of the contemporary refugee subject has presented an unprecedented theoretical, epistemological and methodological challenge to all fields of academic research. Seeking for alternative philosophical modalities capable of liberating refugee representation from the suffocating threat-victim bipolarity, this article critically investigates Giorgio Agamben and Judith Butler's theoretical perspectives on refugee subjectivity. Section 1 systematises the dominant tropes of refugee representation either as dehumanised threats or depoliticised victims. Section 2 introduces the readers to Giorgio Agamben's emblematic homo sacer as a potentially fertile reconceptualisation of refugee subjectivity. In this context, Judith Butler's critique on the Agambenian bare life is presented in two core pillars. Following one Butlerian claim, we trace the Agambenian inadequacy to successfully overcome the contemporary threat-victim mode of refugee representation in the absence of an empowering theoretical account of the homo sacer's agentic and resisting capacities. In Section 4, we explore Judith Butler's main argument regarding the constitutively political character of vulnerable refugee existence. By designating the Butlerian constellation of vulnerability and agency as an invigorating alternative perspective on modern refugee representation, we finally argue that Butler's epistemological framework provides a more agonistic and nuanced theorisation of refugee subjectivity than Agamben.

Keywords: refugee subjectivity, European refugee crisis, Judith Butler, Giorgio Agamben, vulnerability, homo sacer, sovereignty, resistance

\section{Introduction}

In his thorough analysis of Hannah Arendt's diachronic article "We refugees" (1943), Giorgio Agamben traces in the figure of the refugee, the radical emergence of an eminently inverted historical conscience. By extrapolating the Arendtian oracular illustration of the ones "that have lost all rights" ${ }^{1}$ in the theorisation of the contemporary gradual erosion of the constitutive narratives of modernity, Agamben argues that the refugee subject constitutes the sole category that enables us to foresee an arising and drastically

1 Arendt, The Origins of Totalitarianism.

\footnotetext{
* Corresponding author: Ariadni Polychroniou, Department of History and Theory of Law, Law School of Athens, National and Kapodistrian University of Athens, Athens, Greece, e-mail: apolichroniou@hotmail.com
} 
self-reconstructing political community within the forcefully transforming socio-political conditions of our time. ${ }^{2}$

Under this intellectual perspective, the massive emergence of an absolutely heterogeneous political subject, i.e. the acting and talking figure of the de facto - or, more rarely de jure - stateless refugee in the internal realm of a national legal order, becomes the most intractable riddle of the postmodern political condition. Reconstituted as the new multitude in Hardt and Negri's ground-breaking theory, ${ }^{3}$ substituting the working class as the new bringer of change in current post-Marxist approaches, or illuminated as the catalyst of an overwhelming redefinition of Europe's political identity in Slavoj Žižek's recent works, ${ }^{4}$ the postmodern refugee subject inaugurates, in all respects, a radical new ontology. This freshly emerged political actor incarnates both a challenge and a paradox. She problematises and destabilises, via the mere fact of her existence, the central milestones of modernity: modern social structure, national sovereignty, the Westphalian state system, the notion and the limits of citizenship, the content of Human Right Declaration, the primacy of the West, as well as the dominant epistemological distinctions, cultural narratives, modalities of protest and lived experiences of political belonging.

In this academic article, we will attempt to reconceptualise the discursive construction of the refugee subject by surpassing the hegemonic illustrative threat-victim binary. In particular, we will argue that Judith Butler's latest ethico-political theory constructs the most cohesive framework for the critical theorisation of the refugee subject in terms of a political actor that is both agentic and vulnerable. In order to convincingly support the article's main argument, we will firstly present the dominant representation of refugee subjects as either threats or victims with the aid of critical interdisciplinary approaches. In the next part, we will endeavour to overcome this threat-victim binary by examining modern refugee subjectivity through the enigmatic notion of the homo sacer, a theoretical figure re-developed by political philosopher Giorgio Agamben and repeatedly used in the last decade by different branches of philosophy, sociology and anthropology for the current illustration of the refugee subject. In this context, we will systematise Judith Butler's critique on the Agambenian bare life in two core pillars: while we will critically defend Agamben against the Butlerian misconception of the apolitical texture of bare life, we will undeniably accept the Butlerian claim on Agamben's depoliticising methodology. Following the second Butlerian claim, we will trace the Agambenian inadequacy to successfully overcome the contemporary threat-victim mode of refugee representation in the absence of an empowering theoretical account of the homo sacer's agentic and resisting capacities. In Section 4, we will highlight Judith Butler's core argumentation on the performatively political character of refugee existence and explore the Butlerian constellation of vulnerability and agency as a more invigorating alternative perspective on modern refugee representation. By designating refugee agency, resistance and decision-making as political qualities of lives exposed to conditions of absolute precarity, socio-political alienation, material deprivation and symbolic-cultural othering, we believe that the Butlerian epistemological framework successfully overturns the hegemonic threat-victim binary, without erasing neither refugee intentionality nor refugee precarious position.

\section{The bipolar construction of the modern refugee subject as dehumanised threat or depoliticised victim}

In their current comparative research on the dominant visualisation of refugee subjectivities in the realm of the European televisual and print media, Lilie Chouliaraki and Tijana Stolic, ${ }^{5}$ as well as Rafal Zaborowski

\footnotetext{
2 Agamben, Al di là dei diritti dell'uomo.

3 Hardt and Negri, Multitude.

4 Žižek, Die neue Klassenkampf.

5 Chouliaraki and Stolic, "Rethinking Media Responsibility in the Refugee 'Crisis'.”
} 
and Myria Georgiou, ${ }^{6}$ trace the dominant hetero-representation of the refugee crisis' subject through the discursive threat-victim bipolarity. Via a semiotic analysis of refugee subjects' media illustrations in ideologico-politically distinct newspapers of five different European countries (Greece, Italy, Hungary, UK and Ireland), the first two researchers confirm the symbolisation of the refugee in various media as the a priori non-human. They further notice that the refugee subject perceives the form of the oriental threat or of the helpless victim depending on the described event or the political direction of each newspaper. This dichotomous schema has been explored and critically theorised in a large number of interdisciplinary scientific studies regarding the formation of the refugee identity, ranging from philosophy and sociology to political geography and critical ethnography. ${ }^{7}$

Through the comparative overview of multiple theoretical contributions, we are in a position to approach the conceptual features of the refugee depiction's dual character. In the escalating refugee crisis of our time, an alarming perception of refugee subjects as threats is socially reproduced, politically recycled and even institutionally established. Under this xenophobic representation, refugees are depicted in terms of a threatening mass of hyper-masculine, aggressive and heathen intruders that simultaneously wish to tamper the national homogeneity, Christian religion and pristine civilisation of the European States of the first arrival and to perforate the external bulwarks of the democratic, free, rational and culturally superior West. This first discursive construction of the refugee-threat usually becomes visualised via the distanced broadcast of massive refugee flows of allegedly Muslim origin, young age, corporeal strength, brown skin and male sex, endeavouring to cross the borders of a European country or dispersing in its mainland. These mediated images function as a cultural validation for the reproduction of racist, nationalist and Islamophobic perceptions regarding the host country's national supremacy and the West's cultural dominance. At the same time, this polemic representation of refugees as threats against each host country's democratic heritage and national sovereignty is commonly used as a political reassertion for the intense securitisation of European borders and the justification of violent, or even lethal, push-backs.

On the contrary, a second, more generous trope of refugee representation is parallelly reproduced. This alternative mode crystallises refugee subjects in terms of an ahistorical and passive quintessence of vulnerability, by focusing on the close photographic capture of children, women, parents and the elderly: their traumatic faces dramatise the constitutional pain of refuginess and reify the Western subject's voiceless, inferior and helpless Other. Forged through symbolic substitutions and imaginative processes of "infantilisation" and "feminisation," the articulated refugee subject seeks for protection by abnegating her political substance, self-narrative capacity and moral agency, while she enters a radically asymmetrical ethicopolitical relation of supervision and paternalism with the philanthropist Western citizen. The victimisation of refugee subjects successfully inflames feelings of empathy, moral indignation and some sort of awareness raising and active mobilisation among Western citizens, since it contributes to the augmentation of philanthropic initiatives, humanitarian donations and volunteer action. Nevertheless, this type of refugee depiction is still attached to a hetero-representative perception of refugee subjects as dependent, passive and compulsorily grateful receivers of humanitarian aid. As a result, the illustrative victimisation of refugees drastically erases their genuine demands, experiences, feelings and needs. It further hinders the development of a mutual cultural-political bond between refugee and non-refugee subjects, as it constructs a profoundly unequal and quasi-colonial moral relation between the generous, culturally superior and symbolically male Western protector and the feminised, vulnerable, anonymous and orientalist refugee body.

In the opinion of Chouliaraki and Stolic, the illusively antithetical representations of the refugee subject as a threat or a victim are interchangeable and mutually complementary. In fact, both of them equally

6 Zaborowski and Georgiou, "Gamers Versus Zombies? Visual Mediation of the Citizen/Non-Citizen Encounter in Europe's "Refugee Crisis."

7 E.g. Nyers, "Emergency or Emerging Identities? Refugees and Transformations in World Order;” Berry et al., Press Coverage of the Refugee and Migrant Crisis in the EU; Owens, "Beyond 'Bare Life';” Judge, Refugee Advocacy and the Biopolitics of Asylum in Britain The Precarious Position of Young Male Asylum Seekers and Refugees; Fauser, "Transnational Migration - A National Security Risk? Securitization of Migration Policies in Germany, Spain and the United Kingdom.” 
contribute to the dehumanisation and depoliticisation of the subject in question, while each of them can be easily converted in the Western citizen's imaginary to the other, depending on the respective media representation of the refugee crisis:

\begin{abstract}
These two tropes of visual representation, however, should not be seen as antithetical to each other. Victimhood and threat are, in fact, tactically interchangeable moral claims that variously configure the humanity of refugees across time and space. This is the case, for instance, in the shift from empathy for toddler Alan Kurdi's death to outrage for terroristrefugees, in the course of weeks - September to November's Paris attacks (Lenette and Cleland, 2016: 77). It is not, therefore, the distinct performative force of each category that dehumanises refugees, as the literature has it, but also, importantly, their substitutability. This performative volatility of news images, which variously constitutes refugees within changing discourses of in/humanity lies at the heart of the moralising power of public imagery. ${ }^{8}$
\end{abstract}

One other newly emerging modality of refugee self- and hetero-representation is developed through the ambiguous figure of the zombie. This cyborg transmutation takes place in the cultural unconscious of Western citizens through the identification of the refugee subject with a marginal spectre of the human substance and the political community. Depicted either as the confluence of the dead and the alive (ghost, vampire, zombie) or in the form of the human animal (beast, monster, pack, flock), the refugee-zombie trope is connected, according to N. Papastergiades, ${ }^{9}$ to the neoliberal decoupling of refugees/sans papiers/immigrants from the financial production and the market place. We can additionally claim that this zombification is equally produced by the simultaneous intensification of the refugees', asylum seekers' and irregular migrants' spatial confinement, social atrophy, legal uncertainty, political alienation and cultural ostracism. Moreover, the zombification of the refugee population via the attribution of animalistic, mystic or morbid qualities decisively defines, according to Zaborowski and Georgiou, ${ }^{10}$ the ethical encounter and sentimental bond between refugee subjects and Western citizens. Within an allegorical-phantasmal identification of the refugee crisis with a video game, the symbolic illustration of the former as unapproachable and dehumanised sources of fear and disgust - namely as absolutely otherised reflections of an irrational, unconscious and misleadingly humanised evilness - supports the representation of the latter as agentic video game players. According to the rules of this illusory simulation, the powerful, intelligent and rational human players - the Western citizens - act through their gallant, strong, male, white avatars, i.e. the real-life soldier at the borders, the policeman in the mainland or the state officer in the refugee camps; all these figures symbolically serve the Western society by heroically protecting its national homogeneity and precious European heritage against the hordes of refugee-zombies. However, this newly acquired cyborg identity simultaneously signifies some of the most positive qualities of the radically fluid, fragmented and multidimensional refugee subjectivity. Forged through temporal and spatial disconnectedness, continuous mobility, countless cultural interactions and political encounters, the contemporary refugee inaugurates the postmodern emergence of a formerly unthinkable position within the European Nation-State - a re-politicised and re-humanised political subject that acts, demands and resists despite the fact that she is non-Western and non-citizen.

In light of the above observations, we can understand that common refugee representations cannot be perceived as ontologically stable, uniform or homogenised substances. Rather, they shall be seen as powermediated and hegemonically structured discursive results of intensified processes of othering. Under the current neoliberal bio/thanatopolitical production of the Other, the representation and regulation of the modern refugee crisis include technologies of new bipolar subject-formations, which mutually construct one another externally, captured in an eternal dialectical exchange: the refugee-subject and the citizensubject. ${ }^{11}$ Through the dominant production of refuginess in terms of a non-Western, non-civilised, non-

8 Chouliaraki and Stolic, “Rethinking Media Responsibility in the Refugee 'Crisis', 1167.

9 Papastergiades, “Wog Zombie."

10 Zaborowski and Georgiou, "Gamers Versus Zombies? Visual Mediation of the Citizen/Non-Citizen Encounter in Europe’s 'Refugee Crisis'."

11 For an interesting account on the intersection between citizenship studies and modern refugee studies through the theorisation of informal refugee and immigrant political acts in terms of alternative, performative, resisting or active citizenship, see 
agentic, non-rational, non-male and non-citizen hypostasis, the non-refugee subject consequently emerges in the Western imaginary as the positive reflection of all the above negative qualities. This discursive mirroring leads to the narcissistic reconstruction of the Western self as sovereign, powerful and selfauthored while re-vitalising the weakened notion of citizenship:

In the new, current context where the social contract is being dissolved (cf. Kirtsoglou 2010), where frequently one cannot see how "the fundamental social institutions that surround us - police, schools or financial institutions - exist for our benefit" (Graeber 2014: 76), citizenship is increasingly established in the public consciousness through its distinction to the "non-citizenship" of the migrant subject. In a climate of insecurity exacerbated by the international financial crisis as well as state and non-state terrorism, one person's perceived security is experienced relative to another person's precarity. Ultimately, in an era when the definition of what constitutes a "worthy life" (Narotzky and Besnier 2014) and the question of whether this can ever be achieved are not straightforward matters; the realization of our very existence passes partly through the perishing Other. What is established and performatively constructed at the fence of Evros and at the bottom of the Aegean Sea is more than just state sovereignty, borders, or the current biopolitical and/or thanatopolitical paradigm. The ecstatic temporality (Heidegger cf. 1927[1968]) of other people's precarious journeys and impersonal deaths is where both our bios and zoë are being produced and enacted, while the difference between them is being rapidly and blatantly reduced to the bare minimum. ${ }^{12}$

By strengthening nationalistic and Eurocentric narratives, this illusory extraction of two absolutely antithetical identities further undermines the potential of an alternative ethical encounter between refugees and non-refugees, which could be structured by equality, solidarity and mutual respect. Without such a moral, sentimental and political bond, the relation between refugees and citizens will constantly reify the bipolar ontologies of Self-Other ${ }^{13}$ and obscure the mediating topologies and common grounds for mutual solidarity, non-identitarian resistance and transcultural understanding.

After the above brief description of the refugee subject's dominant perception within the cultural, imaginative and socio-political discursive frames of European host states, we are proceeding with the pressing question of our article. Can we currently re-imagine an alternative theoretical modality of conceiving refugee subjectivity as substantially political by maintaining a way to designate refugee agency, resistance, heterogeneity and struggle, without erasing the refugee subject's maximised vulnerability, systemic violence and trauma? In the next two sections of this article, we will critically present two crucial philosophical approaches that may potentially liberate refugee representations from the suffocating threat-victim bipolarity.

\section{The refugee as "bare life": A re-articulation of refugee subjectivity through Giorgio Agamben's homo sacer}

In the first volume of his Histoire de la sexualité, the French philosopher Michel Foucault argues that the Aristotelian distinction between $z o \bar{e}$ and bios is dissolved through the politicisation of biological life and its subsumption to the power technologies of scientific surveillance and state regulation. According to Foucault, this disintegration constitutes the fundamental threshold of modernity. By critically overturning this classic Foucauldian conceptualisation of the exclusively modern emergence of biopower, Giorgio Agamben claims that the inclusion of bare life in the political realm transhistorically represents the primordial and mystical nucleus of sovereign power. Under this perspective, Agamben perceives the modern intensification of the biopolitical reproduction of submissive bodies as a verification, and not as a

Nyers, Rethinking Refugees Beyond State of Emergency and Irregular Citizenship, Immigration, and Deportation; Gündoğdu, Rightlessness in an Age of Rights; Saunders and Hayden, "Solidarity at the Margins;" Sassen, "The Repositioning of Citizenship;" and Guests and Aliens; and Tyler and Marciniak, Protesting Citizenship.

12 Kirtsoglou and Tsimouris, "Il était un petit navire," 7.

13 See Ahmed, Strange Encounters. 
protogenic discovery, of the indissoluble interweaving between sovereign power and bare life. In evidence of the biopolitical texture of archaic power, Agamben dredges up, from the depths of history, the most enigmatic figure of ancient Roman law: the sacred man (homo sacer). The characterisation homo sacer signifies the person that was legally defined as simultaneously killable and unsacrificed, since his murder would be unpunishable by the law and his death could not count as a sacrifice to the gods. By rejecting a series of early sociological and ethnographic interpretations of the sacred man's killability and unsacrificability in terms of a theory on the ambivalence of the Sacred, Agamben re-establishes homo sacer's peculiar juridico-political position as a simultaneous double exception from both the polis of the people and the divine realm of the gods. For Agamben, homo sacer constitutes, therefore, a boundary notion that resides in an unapproachable zone of indistinction and continuous transition between man and beast, city and forest, positive law and divine will, nature and culture.

Trapped in the unconcealed violence of the constant probability of an unpunishable death, bare life becomes sacred by virtue of its submission to an asymmetrical power relation with the sovereign ("originary political relation") and to a synchronic inclusion in the juridico-political order as an exception ("originary exception"), which externally constructs the limits and the character of the political by becoming its exclusive inclusion ("esclusione inclusiva"):

The political sphere of sovereignty was thus constituted through a double exclusion, as an excrescence of the profane in the religious and of the religious in the profane, which takes the form of a zone of indistinction between sacrifice and homicide. The sovereign sphere is the sphere in which it is permitted to kill without committing homicide and without celebrating a sacrifice, and sacred life - that is, life that may be killed but not sacrificed - is the life that has been captured in this sphere. ${ }^{14}$

Homo sacer's obscure juridico-political condition is not exclusively codified in the cryptic description of the archaic Roman law, since it is additionally traced in the discrete mystic figures of European premodern societies, as, for example, in the folkloric figure of the wolf/werewolf/human-wolf that has been ostracised (banned) from the political community and dwells between two different worlds, without belonging to any of them. Traversing European history, the expelled life of the sacred man is rebuilt within the Agambenian framework as the proto-political element of the bond between the sovereign, "with respect to whom all men are potentially homines sacri" and homo sacer, "with respect to whom all men act as sovereigns." Constituting the eternal mystic foundation of political power and constructing a hybrid modality of indifference between political bios and biological zoē, sacred life becomes politicised through submission to the sovereign will: in reality, nuda vita becomes the Urphänomen of politics due to its essential killability. It shall be highlighted at the present point that the Agambenian bare life is neither identified with the mere physical being or biological existence, nor with the enjoyment of a full political life. It is, thus, reconceptualised as both an amalgam and hybrid, namely as a threshold notion that demarcates and includes both of the above poles through the emergence of a "cyborg” life. The bare life's sacrality, therefore, derives from the deprivation of all rights and a radical exposure to death.

Very interestingly, Agamben rereads the Hobbesian state of nature ${ }^{15}$ in terms of an internal principle of the political realm, according to which everybody can be treated by anyone else as a homo sacer (homo hominis lupus). This imaginary state of absolute exception can be overturned by a pseudo-contract, which introduces bare life within the city under the constant authority of the sovereign. Therefore, for Agamben, the constitutive juridico-political bond of modernity is not founded in the social contract. On the contrary, it derives from the primordial power of the sovereign ban that is, from the political power's capacity, to biopolitically produce sacred men with absolutely killable lives. The variant definition of these expelled forms of life externally constructs the limits of the modern political through their inclusive exception.

This undecipherable structure of political power, the sovereign ban, is even less traceable in the political organisation of modernity. In more progressed societies, homo sacer is not predefined with

14 Agamben, Homo Sacer, 53.

15 Hobbes, Leviathan. 
precision by the law, the customs or the political community and is clearly not expelled from the city in literal terms. In all respects, the power production of the sacred man constitutes a historico-culturally variable process, given that each society dominantly defines their homines sacros by cautiously guarding the boundaries of its single political ontology. The distinctiveness of modern biopower, however, is located in the intensification and generalisation of the power processes that establish life - and death, respectively - as the higher stake of both the sovereign-political and the newly emerged sovereign medical and scientific discourse:

If it is true that the figure proposed by our age is that of an unsacrificeable life that has nevertheless become capable of being killed to an unprecedented degree, then the bare life of homo sacer concerns us in a special way. Sacredness is a line of flight still present in contemporary politics, a line that is as such moving into zones increasingly vast and dark, to the point of ultimately coinciding with the biological life itself of citizens. If today there is no longer any one clear figure of the sacred man, it is perhaps because we are all virtually homines sacri. ${ }^{16}$

The transition into modernity signals the gradual infiltration of political power into the deeper and wider aspects of human life. In modernity, biopolitics turns into thanatopolitics, as scientists, doctors, economists, lawyers and technocrats claim the throne of the sovereign. For Agamben, this encompassing erosion of life by the modern biopower contributes to the emergence of a radically new locus of absolute exception and pure sovereignty: the modern concentration camp. While studying the unprecedented politicisation of bare life in the Third Reich, Agamben develops a lucid re-interpretation of the concentration camp. His novel conceptualisation does not perceive the camp in terms of an isolated historico-political event of absolute atrocity and does not exclude the potential repetition of an equally horrifying condition thanks to the newly developed democratic reflective of post-war societies.

On the contrary, Agamben understands the camp as an inherent element of modernity itself. According to his analysis, the modern concentration camps are constantly reified in modernity every time when the exception becomes the uncontested rule, when the sovereign affects bare life immediately and when the law gets inseparably interconnected with the fact. Embedded in a spatial zone of absolute indifference between the enactment and the implementation of rules, the modern concentration camp is reproduced out of the realm of the law as an exception of both administrative and penal legislation. In return, the camp produces, by its own, purely bare lives, hopelessly exposed to its intensified and undoubted sovereignty.

The modern concentration camp is therefore theorised as localizzazione dislocante, i.e. a dislocating localisation that captures the modern Nation-State's resisting surplus by regulating the dangerous living exception of the constitutive trinity of land, order, birth - the refugee, the stateless, the immigrant. Partly echoing Arendt, Agamben interprets the continuous multiplication of modern zones, that produce the new hominos sacros of our time, as illustrating proofs of the Nation-State's monumental incapacity to control the total amount of subjects born and residing within its legal authority. As a result, the modern camp fixes the degraded modern state's impotency by managing to collect, absorb and supervise the non-citizen surplus life within its own exceptional order. Hence, the Agambenian camp surfaces as the essential fourth element of the ruptured modern trinity state-nation-land.

Trapped within the power mechanisms of the refugee camp as killable life at the mercy of an undisputed sovereignty, the modern refugee subject transforms into the ultimate resident of this historically contingent zone of indistinction, that is the exemplary homo sacer of late modernity:

If this is true, if the essence of the camp consists in the materialization of the state of exception and in the subsequent creation of a space in which bare life and the juridical rule enter into a threshold of indistinction, then we must admit that we find ourselves virtually in the presence of a camp every time such a structure is created, independent of the kinds of crime that are committed there and whatever its denomination and specific topography. The stadium in Bari into which the Italian police in 1991 provisionally herded all illegal Albanian immigrants before sending them back to their country, the winter cycle-racing track in which the Vichy authorities gathered the Jews before consigning them to the Germans, the Konzentrationslager für Ausländer in Cottbus-Sielow in which the Weimar government gathered Jewish refugees from the

16 Agamben, Homo Sacer, 68. 
East, or the zones d'attentes in French international airports in which foreigners asking for refugee status are detained will then all equally be camps. In all these cases, an apparently innocuous space (for example, the Hôtel Arcades in Roissy) actually delimits a space in which the normal order is de facto suspended and in which whether or not atrocities are committed depends not on law but on the civility and ethical sense of the police who temporarily act as sovereign (for example, in the four days during which foreigners can be held in the zone d'attente before the intervention of the judicial authority). ${ }^{17}$

Both the Agambenian conceptualisation of homo sacer's unsacrificied killability and the radical retheorisation of the concentration camp in terms of the nomos of modernity have been frequently investigated by many contemporary thinkers in relation to the current refugee crisis. In particular, Agamben's political philosophy has been often implemented in the theoretical depiction of the biopolitical and necropolitical production of the modern refugee subject, as well as in the sociological, ethnographic and anthropological research on European refugee camps. ${ }^{18}$

One of Agamben's most intense critiques belongs, however, to the post-structuralist philosopher Judith Butler. Butler argues, in a well-grounded manner, that the Agambenian homo sacer constructs a profoundly inefficient conceptual framework for the theorisation of the modern refugee subject. To prove the above point, Butler confutes the Agambenian bare life in numerous of her works (Vulnerable Life, Frames of War, Notes toward a performative theory of Assembly, Who sings the Nation-State? and The Force of non-violence), by articulating two central arguments against it. At a first level, Butler supports that the indistinct universalisation of becoming homo sacer in Agamben's theory invisibilises modernity's systemic inequalities concerning gender, class, race, ethnicity, religion, sexuality and geopolitics. According to her, a modern subject's ptosis to bare life is not a product of homogenising and symmetric power processes, but an unequal and structural procedure of certain social categories' and populations' dehumanisation and precaritisation.

Additionally, Butler problematises Agamben's apparent lack of a theoretical critique on modern sovereignty. For Butler, the Agambenian illustration of sovereign power as an intertemporal force of absolute invulnerability, immunity and stability leads to a severe political paralysis; she argues that the core Agambenian bipolarity, sovereignty-bare life, forcefully erases all the collective resistances, empowering acts, solidarity actions and personal experiences of the modern hominum sacrorum. Therefore, Agamben's sophisticated development of a theory of sovereignty is heavily criticised by Butler on the grounds that this very theory is not accompanied with an equally detailed philosophical perception of bare life's modalities of agency, experience, will and resistance. According to her, this line of theorising unintentionally validates the unassailable character of sovereignty via the epistemological and methodological elimination of the multi-layered actions, struggles and personalities of vulnerable subjectivities:

\footnotetext{
The focus on the theoretical apparatus of sovereignty risks impoverishing our conceptual framework and vocabulary so that we become unable to take on the representional challenge of saying what life is like for the deported, what life is like for those who fear deportation, who are deported, what life is like for those who live as gastarbeiters in Germany, what life is like for Palestinians who are living under occupation. These are not undifferentiated instances of "bare life" but highly juridified states of dispossession. We need more complex ways of understanding the multivalence and tactics of power to understand forms of resistance, agency, and counter-mobilization that elude or stall state power. I think we must describe destitution and, indeed, we ought to, but if the language by which we describe that destitution presumes, time and again, that the key terms are sovereignty and bare life, we deprive ourselves of the lexicon we need to understand the other networks of power to which it belongs, or how power is recast in that place or even saturated in that place. ${ }^{19}$
}

17 Ibid., 98-9.

18 See Fassin, “Compassion and Repression;” Green, "Performing Border in the Aegean;” Dines et al., "Thinking Lambedusa;” Zembylas, "Agamben's Theory of Biopower and Immigrants/Refugees/Asylum Seekers Discourses of Citizenship and the Implications For Curriculum Theorizing;" Davitti, "Biopolitical Borders and the State of Exception in the European Migration "Crisis;” Ongur and Zengin, "Reading Agamben Backwards;” Rozakou, "The Biopolitics of Hospitality in Greece.” For a negative critique of Agamben's implementation in the refugee crisis discourse, see Owens, "Reclaiming 'Bare Life'?."

19 Butler and Spivak, Who Sings the Nation State?, 41-3. 
The second Butlerian critique rejects the theoretical depiction of refugee subjects in terms of bare life as profoundly apolitical. According to Butler, the vulnerable subject's biopolitical exposure to physical violence, sentimental trauma, material deprivation, legal obscurity and political marginalisation does not entail her entry to a pro-political, apolitical or bestial ontology. As she argues, vulnerable life preserves, even in the scarcest form, the capacity to politically resist, wish, act, prepare and dream:

To be short of protection is not a matter of becoming "bare life" but rather a concrete form of political exposure and potential struggle, at once concretely vulnerable, even breakable, and potentially and actively defiant, even revolutionary. ${ }^{20}$

The Agambenian bare life is therefore perceived by Butler as a depoliticising plunge to the biological or natural existence, a return to an animalistic state of pure $z o \bar{e}$ in the Aristotelian sense. By continuously emphasising the apolitical or pro-political character of bare life, Butler locates the naked life of the Agambenian homo sacer beyond the sphere of the polis and the realm of sovereignty.

By taking into consideration both the repetitive theorisation of the modern refugee subject in terms of a homo sacer and Butler's twofold problematisation of the term, we are in a position to critically re-approach the central question of this article. Is the Agambenian bare life the most fruitful theoretical construction for the representation of the contemporary refugee beyond the threat-victim bipolarity?

Firstly, we have to argue that Butler misinterprets both the hybrid conception of the Agambenian bare life and its core dialectic with sovereign power. As we have observed above, the sacred man echoes, within the frames of the Agambenian theory, the primordial political figure: his constitutive political character emanates from his apriorical exposure to the absolute rule of the sovereign and from his exceptional construction by the sovereign decision. According to Agamben, bare life does not symbolise a pro-political, irrational or bestial return to the natural condition, since this form of existence is decisively located in a zone of absolute indifference between life and death. The sacred man's hybrid condition is, therefore, not physical at all; it originates from political power itself:

Let us now observe the life of homo sacer, or of the bandit, the Friedlos, the aquae et igni interdictus, which are in many ways similar. He has been excluded from the religious community and from all political life: he cannot participate in the rites of his gens, nor (if he has been declared infamis et intestabilis) can he perform any juridically valid act. What is more, his entire existence is reduced to a bare life stripped of every right by virtue of the fact that anyone can kill him without committing homicide; he can save himself only in perpetual flight or a foreign land. And yet he is in a continuous relationship with the power that banished him precisely insofar as he is at every instant exposed to an unconditioned threat of death. He is pure zoē, but his zoē is as such caught in the sovereign ban and must reckon with it at every moment, finding the best way to elude or deceive it. In this sense, no life, as exiles and bandits know well, is more "political" than his. ${ }^{21}$

However, this primordially political substance of the Agambenian homo sacer is still deprived of radical agentic, collectively empowering or resisting potentials. Following the first Butlerian argument, we believe that the insuperable and quasi-deterministic relationality between sovereign power and bare life excludes a systematic socio-political critique of the complex power correlations and structural injustices that sustain and reproduce the modern refugee's precarious position. Additionally, we claim that the Agambenian description of bare life cannot serve as a coherent conceptual framework for the theorisation of the refugee's agency, collective protests, resistant acts and solidarity alliances. The construction of a biopolitical subject, which is solely politicised through his exposure to the sovereign ban, expunges the multiple constructive, unanticipated and performative modalities of becoming political through breakthrough acts of public appearance, artistic expression, collective gathering and non-violent resistance. Hence, we argue that the Agambenian notion of the homo sacer cannot successfully overcome the suppressing dominant boundary of refugee representation, by providing a rejuvenating perspective on empowering, struggling

20 Butler, Notes Towards a Performative Theory of Assembly, 186.

21 Agamben, Homo Sacer, 103. 
and revolting aspects of the refugee subject. We, therefore, support that we need to move forward to a radically new conceptual paradigm of theorising refugee subjectivity.

In Sections 4 and 5, we will examine Judith Butler's constellation of vulnerability and agency as a theoretical framework capable of de-essentialising refugee precarity, reconstructing imperceptible everyday refugee acts as profoundly political and re-establishing vulnerable subjects' resistances as empowering and embodied forms of collective performativity.

\section{The refugee subject in Judith Butler's ethico-political theory: Towards a dialectical paradigm of vulnerability and intentionality}

In Section 5, we will explore Judith Butler's main argument regarding the constitutively political character of vulnerable refugee existence and evaluate the novel Butlerian conjuncture of vulnerability and agency as a direct re-theorisation of refugee subjectivity. By presenting the following core aspects of the recent Butlerian ethico-political theory, we will attempt to designate Butler's theoretical capacity to overcome the threat-victim bipolarity and provide a more nuanced perspective of refugee subjectivity than Agamben does.

In her interesting dialogue with Gayatri Spivak in Who Sings the Nation-State?, Butler argues that the refugee subject's expulsion from the legal order of the country of her arrival does not signify her ostracism from the sphere of the political:

The point is to suggest that we cannot presume a movement from an established state to a state of metaphysical abandonment; these movements are more complex and require a different kind of description. Only one of these is described by the act of sovereignty by which constitutional protec-tions are withdrawn and suspended. An abandonment by such protections can hap-pen in different ways, and it is not always possible to suppose that those protections were intact prior to such an abandonment. Moreover, the populations we are trying to describe, those who have become effectively stateless, are still under the control of state power. In this way, they are without legal protection but in no way relegated to a "bare life": this is a life steeped in power. And this reminds us, crucially, that power is not the same as law. ${ }^{22}$

Trapped in a refugee camp or irregularly wandering in the foreign mainland, the refugee subject, remains, despite her deprivation of essential judicial protection and constitutional rights, profoundly infiltrated by power mechanisms and dominant processes of dehumanisation and precaritisation. The subject in question is, in fact, not expelled from the realm of state control like a stray animal, given that she becomes exposed, since the moment of her arrival, to intense biopolitical procedures of supervision, classification and discipline. In particular, refugee subjects are constantly categorised according to prefixed and stereotyped standards based on their country of origin, ethnicity, gender, colour, religion, age and class. In addition, they suffer from a detailed control of every aspect of their everyday lives within the camps, while their accountability is scrutinised and their vulnerability is questioned during their asylum interviews. Moreover, their lives become even more precarious under the continuous threat of their arrest, imprisonment, refoulement and violent treatment by the police, if they reside out of the camp.

In Butlerian terms, however, embodied vulnerable subjects that get expelled from both the political community and the legal order are re-conceptualised as par excellence political actors. Their political character derives from their subsumption to a pure extraterritorial sovereign power, which overflows the limits of each country's democratic constitutionalism. A similar claim is developed by Butler in regard to the illegal status of war prisoners' indefinite detention in Guantanamo, ${ }^{23}$ the inhumane tortures in Abu Graib,

22 Butler and Spivak, Who Sings the Nation State?

23 See Butler, "Indefinite Detention." 
the racialised pattern of USA' correctional system and the systemic phenomena of femicidio and homophobic attacks. According to Butler, the hegemonic reproduction of apriorically disposable and ungrievable forms of subjects functions as a prerequisite for those subjects' arbitrary legal or socio-political expulsion and their subsequent submission to the anachronistic distortion of an absolutely illegitimate power. All the above unjust power mechanisms entail purely political actions that saturate vulnerable subjects with state or generally political authority:

If the state is what "binds," it is also clearly what can and does unbind. And if the state binds in the name of the nation, conjuring a certain version of the nation forcibly, if not powerfully, then it also unbinds, releases, expels, banishes. If it does the latter, it is not always through emancipatory means, i.e., through "letting go" or "setting free"; it expels precisely through an exercise of power that depends upon barriers and prisons and, so, in the mode of a certain containment. We are not outside of politics when we are dispossessed in such ways. Rather, we are deposited in a dense situation of military power in which juridical functions become the prerogative of the military. ${ }^{24}$

However, contrary to Agamben, the Butlerian refugee's political substance is not exclusively forged through the politico-authoritative character of her subjugation to sovereign power. In addition to her exposure to dehumanising conditions of radical dispossession and systemic violence, the refugee subject is primarily politicised as a result of the "performative paradox" of precarious existence. According to Butler, the refugee subject performs acts of political meaning by appearing in the public sphere and expressing, together with other invisibilised social subjects, legally unrecognisable or institutionally unutterable demands for an equally grievable and more livable life. Butler emphatically argues that the plural, multilingual, heterogeneous, public and unexpected protests of constitutionally expelled and hegemonically depoliticised social objects not only re-establish their vulnerable participants as political actors, but additionally redefine, in constructive and subversive ways, the limits of the political. Partially echoing Hannah Arendt's conceptualisation of the public sphere ${ }^{25}$ as a lively political topology emerging through plurality, fluidity and heterogeneity, Butler re-articulates contemporary immigrant and refugee assemblies as eloquent depictions of the radical performativity of non-identitarian political belonging. ${ }^{26}$ Under this Butlerian perspective, the formally illegitimate collective enactment of the political rights of assembly, expression, speech and movement on behalf of illegally or irregularly residing subjects inaugurates performatively the beginning of a new conceptualisation of political subjectivity as a socio-historically variant, open and contested field of continuous re-negotiations and tumultuous re-signalisations. ${ }^{27}$

An illustrating example of such performative politics is traced, according to Butler, in the massive immigrant and sans papiers mobilisations that took place in Los Angeles and numerous other American cities in the spring of 2006. Marching against the extreme penalisation of illegal immigration introduced by the proposed H.R. 4437 legislation on immigration reform, millions of immigrants of mainly Latino origin publicly appeared in the streets, by singing, among other acts of public revolt, the American National Anthem in Spanish. For Butler, this performative exercise of politics ruptures the public sphere in an Antigonean way, ${ }^{28}$ by reconstructing the very definition of the nation and by re-codifying the meaning of democratic participation, political community, linguistic intimacy, coalition politics and the political task of translation. ${ }^{29}$

Therefore, for Butler, the performative paradox of the precarious subjectivities' political struggles constructs a juridico-political aporia that leads to revolt instead of dead-ends. The designation of this

24 Butler and Spivak, Who Sings the Nation State?, 5.

25 See Arendt, The Human Condition. For a feminist reinterpretation of the Arendtian theory as performative, see Honig, "Toward an Agonistic Feminism."

26 See also Butler, "Performativity, Precarity and Sexual Politics."

27 See Butler, Notes Towards a Performative Theory of Assembly; and Butler and Athanasiou, Dispossession.

28 See Butler, Antigone's Claim.

29 The 2006 immigrant protests have presented a field of thorough Butlerian theorising in many of her works. See Butler and Spivak, Who Sings the Nation State?; Butler and Athanasiou, Dispossession; Butler, Notes Towards a Performative Theory of Assembly; and Butler, "Performativity, Precarity and Sexual Politics." 
collective exercise of freedom as a source of politicisation proves to be crucial for the current understanding of refugee subjectivity. Focusing exclusively on the refugee protests of the contemporary mobility crisis, Butler theorises in her recent work The Force of Non-Violence: An ethico-political Bind (2020), the contemporary refugee protests that took place in 2012 in Würzburg, Germany and in 2017 in Calais, France. Both of these distinct modalities of public refugee protests were perceived by Butler as performative exercises of non-violent agonistic action. Through the development of alternative embodied, wordless, dramatic or even theatrical-like mechanisms of political reaction, the current refugee crisis' subjects denounce their systemic oppression, by re-politicising typically non-political gestures and disentangling radical new forms of revolting action and collective resistance.

Their view, widely shared, is that without a political response, the refugees remain voiceless, since a voice that is not heard is not registered, and so it is not a political voice. Of course, they did not put their claim in this propositional form. But they made the point through a readable and visible gesture that muted the voice as the sign and substance of their demand. The image of the stitched lips shows that the demand cannot be voiced and so makes its own voiceless demand. It displays the voicelessness in a visual image in order to make a point about the political limits imposed on audibility. In some ways, we see again a form of theatrical politics that asserts their power and, at the same time, the limits imposed on that power. ${ }^{30}$

According to Butler, modern refugee protests are theorised in terms of a purely embodied action. In this context, the normatively depoliticised, social and fluid body ${ }^{31}$ of the refugee subject acts as a deixis, namely declaratory of the dehumanising conditions of precarious life via the exposure of the refugee's traumas, pain, fear, mistreatment and scars to the public eye. At the same time, the body acts assertively, by carving through this very exposure to systemic violence and structural injustice, a radically emerging personal persistence and a collective will to resist, ally and protest. Besides, the populous assemblies of refugee subjectivities that are not recognised as formal political actors, in public places, such as streets, churches, squares, parks and universities, incarnate their political character in a collective, yet not pre-organised, precarious embodiment. As they synchronically expose their injurable bodies to police or military violence, they collectively carry a profoundly political message of resistance. Finally, refugee protests often include the transmutation of the vulnerable body itself into a canvas of resistance, via, for example, co-ordinated collective hunger strikes, lip sewing practices and other embodied self-destructive acts with apparent political codification.

Hence, the performative reconstruction of refugee subjectivity invests the Butlerian perspective with a more empowering modality of refugee politicisation than the Agambenian homo sacer's dialectic with sovereign power does. By re-establishing refugee subjectivity as embodied, struggling, precarious and agonistic, Butler delineates an alternative theorisation of the refugee's constitutive political character without resulting in the naive beautification of the refugee's extreme juridico-political and material reality. Moreover, this theoretical account of refugee subjectivity is more capable of echoing the complex and multiple political protests and collective movements of refugee subjects that have not been systematically theorised yet in both political science and social, philosophical and anthropological fields of research. ${ }^{32}$

Within this scope, the Butlerian theory destabilises the dominant threat-victim bipolarity by introducing an alternative paradigm for the conceptualisation of refugee subjectivity: a constellation, rather than a polarity, of vulnerability and agency..$^{33}$ In the remaining pages of this article, we will systematise Butler's conjuncture of vulnerability-agency as the most opportune trope for the representation of the refugee subject. Within this context, we shall clarify that the constitutive Butlerian notion of vulnerability is not developed for the first time in respect of the refugee subject's formation. On the contrary, these vital parameters of the Butlerian subjectivation process and ethico-political theory are explored, enhanced, altered and re-systematised in her previous emblematic works: The Psychic Life of Power, Giving an

30 Butler, The Force of Nonviolence, 196.

31 See also Häkli and Kallio, "Bodies and Persons."

32 For an interesting recent collection of academic contributions on immigrant and refugee protests, see Tyler and Marciniak, Immigrant Protest.

33 See also Butler, "Rethinking Vulnerability and Resistance.” 
Account of Oneself, Precarious Life, Frames of War, Dispossession: The Performative in the Political and Notes Towards a Performative Theory of Assembly. However, in her latest work The Force of Non-Violence, Butler processes the 2015 European refugee crisis in more depth, by re-approaching the question of the refugee subject through the lens of her former conceptual framework.

Initially, in this book Butler criticises the paternalistic predefinition of some targeted populations as $a$ priori vulnerable and rejects the homogenised concentration of explicitly different social subjects under one undivided and uniform category or class of the vulnerable. Therefore, she argues that the notion of vulnerability, when it becomes identified with passivity and dependence, is not in a position either to construct an essentialist identity based on common characteristics or to serve as the foundation of a radically new ethico-political relation:

\footnotetext{
The task, I would suggest, is not to rally as vulnerable creatures or to create a class of persons who identify primarily with vulnerability. In portraying people and communities who are subject to violence in systematic ways, do we do them justice, do we respect the dignity of their struggle, if we summarize them as "the vulnerable"? In the context of human rights work, the category of "vulnerable populations" includes those who require protection and care. Of course, it is crucial to bring into public awareness the situation of those who lack basic human requirements such as food and shelter, but also those whose freedom of mobility and rights to legal citizenship are denied, if not criminalized. Indeed, an increasingly large number of refugees have been abandoned by so many nation-states and transnational state formations, including, of course, the European Union. And the United Nations High Commissioner for Refugees estimates there are nearly 10 million stateless people now living in the world. ${ }^{34}$
}

By illuminating the refugee subjects' often imperceptible and unrecognised everyday acts of planning, moving, aiding, hiding, envisioning, protesting and struggling as primarily energetic and intentional, Butler reestablishes agency as a constructing element of refugee subjectivity. In this way, she positively resignifies refugee acts that are invisibilised in the Western institutional and political discourse in an attempt to problematise the dominant narrative of refugee victimisation. In this context, the Butlerian refiguration of refugee subjectivity as a constellation of vulnerability and agency restructures a conservative content of agency as widely publicised, remarkable and strictly singular. According to Butler, agency is not the opposite of vulnerability, as it does not take the form of the heroic overcoming of precarity and it does not vindicate the newly acquired power of an individualised and exceptional subject. On the contrary, agency is intertwined, in Butlerian terms, with vulnerability, as it surfaces within the most precarious conditions and it manifests the precarious subject's persistence to live, resist and demand:

\footnotetext{
At the same time, those who have lost infrastructural support have developed networks, communicated timetables, and sought to understand and use international maritime laws in the Mediterranean to their advantage in order to move across borders - to plot a route and to connect with communities that can provide support of one kind or another, such as squatting in vacated hotels with accommodating anarchists. Those amassed along the borders of Europe are not precisely what political philosopher Giorgio Agamben referred to as "bare life" - that is to say, we do not recognize their suffering by further depriving them of all capacity. Rather, they are, for the most part, in a terrible situation: improvising forms of sociality, using cell phones, plotting and taking action when it is possible, drawing maps, learning languages, though in so many instances those activities are not always possible. Even as agency is blocked at every turn, there still remain ways of resisting that very blockage, ways of entering the force field of violence to stop its continuation. ${ }^{35}$
}

Via the above theoretical rewritings, Butler sets her central inquiry concerning the refugee crisis: "Is there, then, a way to name and counter forms of necropolitical targeting such as these without producing a class of victims?."36 Seeking new epistemological and conceptual patterns for the transparent depiction of current forms of asymmetrical necropolitical ${ }^{37}$ management of certain populations and social subjects, Butler theorises the refugee identity as a constellation of vulnerability and agency through the radical redefinition of both terms. While focusing on refugees' resistances, experiences, narratives and self-

34 Butler, The Force of Nonviolence, 194.

35 Ibid.

36 Ibid, 196.

37 See Mbembe, "Necropolitics” and Necropolitics. 
representations, Butler firmly believes that vulnerability shall not be wiped out of the critical re-theorisation of the refugee identity. The opposite alternative of the utopian-imaginative eradication of the modern refugee's extreme precarity, leads, according to her, to the distorted concealment of systemic structures of inequality, oppression and injustice. The erasure of refugee vulnerability further contributes to the detrimental misconception of the hegemonic frames of recognisability and intelligibility, which equally induce the multi-faceted precarious condition of the refugee.

The recognition of this structural precarity neither naturalises vulnerability in terms of an inherent characteristic of the refugee subject, nor essentialises passivity, weakness and dependence as constructive elements of her identity. We argue that at a first, more socio-political, level, the Butlerian designation of precarity targets at the denaturalisation of the refugee subject's vulnerable identity through the critical underlining of the multiple structural, material, technical, geopolitical, judicial, sociocultural and linguistic factors that alienate her life: flight from her country of origin due to war, civil conflict or fear of prosecution, torture and execution; lethal riskiness of crossing the sea; transaction with smugglers; dangerous transversal of borders; landing in hostile and racist country; linguistic and cultural difficulty in understanding the complicated and often changing asylum procedures; confinement and dehumanising living in refugee camps; lack of access to a lawyer, social worker and interpreter; prohibition to move to another European country than the country of the first arrival; potential refoulement to Turkey; deficiency in access to educational programmes and language learning classes; rigidity of state authorities; high risk of asylum application's rejection; prohibition to apply for a legitimate job and to move freely within the country; reduced or none public health access; marginalisation from a political community; and xenophobic, Islamophobic and nationalist treatment by the host country's citizens. The critical de-essentialisation of the refugee's vulnerability emphasises these multiple factors that construct and reproduce the precarious condition of refuginess. Such a line of theorising targets the political problematisation of the nefarious asylum and immigration policies of the European Union, the inexpedient national legislations, the bureaucratic procedures and the informal regulation practices of the current refugee crisis. At the same time, the Butlerian critique contributes to the reflective confutation of xenophobic stereotypisations of refugee subjects, as well as to a deeper perception of international historic and geostrategical sources of the human mobility.

Moreover, refugee vulnerability is theorised, in Butlerian terms, as a fundamental withdrawal of the multi-layered supportive plexus that maintains and preserves life. More concretely, the dehumanising refugee condition is interpreted as the combined outcome of the loss of state protection, peace, human right guarantees, home, security and stability in the country of origin as well as the inability to regain access to family structure, privacy, language, proper medical care, social respect, political community, creativity, work, education, judicial protection, equal relationships and free mobility in the European country within which the asylum application has been - voluntarily or mandatory - filed. Therefore, vulnerability does not become a personal essence or a collective construction of refuginess. On the contrary, Butlers re-examines refugee vulnerability as an amalgamation of the traumatic-and sometimes even lethal - deprivation of the social, political and emotional bonds that construct all individuals as recognisable subjects and establish them as social actors through material infrastructures, political freedoms, state protection and rights acquisition.

Finally, the Butlerian reconceptualisation of refuge vulnerability in terms of a critical absence of this vital protection nexus may potentially revive and alter the ethical encounter between refugee and nonrefugee subjects. The de-essentialisation of the vulnerable refugee identity does not only disrupt the normative bipolar construction of threat-victim, but also additionally destabilises the equally polar Eurocentric agency-passivity trope of representing the relations between Western citizens and refugee subjects. By critically re-approaching refugee vulnerability as a systemic socio-politically induced condition of maximised precarity, the Western subject could reflectively reconsider her privileged position in terms of an evenly dependent, relational and precarious social ontology. Rather than an autocentric individual achievement of self-sustainment, the comparatively more guaranteed protection of a Western life is perceived under this Butlerian scope as a product of the complex juridico-political enshrinements, technical-material infrastructures, geostrategical positions and historical-institutional foundations of the 
political community within which she lives. Under this alternative perspective, neither the social category of the refugee subject nor the legal-political position of the (Western) citizen subject reflect firm, stable and ahistorical qualities. On the contrary, the Western subject's reflexive acceptance of the historical fluidity and socio-political dependence of refugee vulnerability may undermine the self-referential narcissistic mirroring of the refugee figure as the inscrutable or inferior Other of the Western Self. The crucial overcoming of the hallucinating Western interpretation of the refugee as a helpless victim and the Self as an invulnerable, transparent and self-reliant entity could, therefore, recreate a more nuanced political relation between refugee and non-refugee subjects. By re-conceiving vulnerability under the Butlerian perspective, the refugee/non-refugee bond can surpass the bipolar threat-victim discursive economy and be recreated as a mutual commitment to the retrieval of plural, heterogeneous and non-identitarian social relations, political struggles, cultural interactions and solidarity alliances.

\section{Conclusion}

As long as the dominant socio-cultural trope of refugee illustration remains enclosed in the distorting hetero-representative threat-victim binary, we imperatively need to continue seeking alternative interdisciplinary frameworks for the depiction of the refugee subject. Echoing the necessity for a revolutionary paradigm shift, this article attempted to contribute to the epistemological reinterpretations of the contemporary refugee crisis by associating Giorgio Agamben's and Judith Butler's philosophical thinking with the question of the refugee subject. In this context, we argued that the Butlerian reconceptualisation of refugee subjectivity as both precarious and agentic constitutes an innovative jumping-off point for the re-imagination of new modalities of refugee representation beyond the threat-victim polarity. By presenting both Butler's theoretical framework and Agamben's homo sacer, we endeavoured to designate two advantageous qualities of the Butlerian ethico-political perspective in respect of the refugee subject's theorisation. Contrary to Agamben and other theorists of the biopolitically disposable existence, we claimed that Butler's performative politics provides a more empowering and agonistic foundation for the political character and the politicisation process of the refugee subject. Moreover, we asserted that Butler overturns the hegemonic threat-victim binary more drastically than Agamben, as she accomplishes the ambitious theoretical task of conjoining vulnerability and agency in terms of a unified constellation rather than a polar opposition. On the strength of this critical rapprochement, we therefore conclude that the Butlerian theoretical framework can elucidate additional aspects of the modern refugee crisis, such as the performative texture of collective refugee resistance, the retrospective acceptance of Western subjects' constitutive interdependency and the empowering reconstruction of non-identitarian solidarity bonds between refugee and non-refugee subjects.

Acknowledgments: I would like to sincerely thank the editors of the topical issue, Dr. Nicole Des Bouvrie and Dr. Laura Hellsten, as well as the three anonymous reviewers and the Editorial Team of Open Philosophy, for their substantial contribution to the enhancement of this academic research and the publication of this article.

Funding information: Author states no funding involved.

Conflict of interest: Author states no conflict of interest.

\section{References}

Agamben, Giorgio. Homo Sacer: Sovereign Power and Bare Life. Stanford: Stanford University Press, 1998.

Agamben, Giorgio. Al di là dei diritti dell'uomo. Torino: Bollati Boringhieri editore, 1996. 
Ahmed, Sarah. Strange Encounters: Embodied Others in Post-Coloniality. London: Routledge, 2000.

Arendt, Hannah. The Origins of Totalitarianism. New York: Harcourt, Brace, Jovanovich, 1973.

Arendt, Hannah. The Jewish Writings, edited by Jerome Kohn and Ron H. Feldman. New York: Schocken, 2007.

Arendt, Hannah. The Human Condition. Chicago: University of Chicago Press, 2018.

Berry, Mike, Kerry Moore, Marina Morani, Inaki Garcia-Blanco, Bernard Gross, Tina Askanius, and Tobias Linne. Press coverage of the refugee and migrant crisis in the EU: A content analysis of five European countries. Geneva: United Nations High

Commissioner for Refugees, 2016.

Butler, Judith and Spivak Gayatri Chakravorty. Who Sings the Nation State? Language, Politics, Belonging. Calcutta, New York, London: Seagull Books, 2007.

Butler, Judith. Frames of War: When Is Life Grievable?. London and New York: Verso Books, 2009.

Butler, Judith. Antigone's Claim. New York: Columbia University Press, 2002.

Butler, Judith. Precarious Life: The Powers of Mourning and Violence. New York: Verso Books, 2004.

Butler, Judith. "Performativity, Precarity and Sexual Politics." AlBR, Revista de Antropología Iberoamericana 4:3 (2009), i-xiii. Butler, Judith and Athena Athanasiou. Dispossession: The Performative in the Political. Cambridge: Polity Press, 2013.

Butler, Judith. Notes Towards a Performative Theory of Assembly. Cambridge: Harvard University Press, 2015.

Butler, Judith. The Force of Nonviolence: An Ethico-Political Bind. London and New York: Verso Books, 2020.

Chouliaraki, Lilie and Tijana Stolic. "Rethinking Media Responsibility in the Refugee 'Crisis': A Visual Typology of European News.” Media, Culture and Society 39:8 (2017), 1162-77.

Chouliaraki, Lilie."Symbolic Bordering: The Self-Representation of Migrants and Refugees in Digital News." Popular Communication 15:1 (2017), 1-18.

Chouliaraki, Lilie and Myria Georgiou. "Hospitability: The Communicative Architecture of Humanitarian Securitization at Europe's Borders.” Journal of Communication 67:2 (2017), 159-80.

Davies, Thom, Arshad Isakjee, and Surindar Dhesi. "Violent Inaction: The Necropolitical Experience of Refugees in Europe." Antipode 49:5 (2017), 1263-84.

Davitti, Daria. "Biopolitical Borders and the State of Exception in the European Migration 'Crisis'." The European Journal of International Law 29:4 (2018), 1173-96.

Dines, Montagna and V. Ruggiero. "Thinking Lambedusa: Border Construction, the Spectacle of Bare Life and the Productivity of Migrants." Ethnic and Racial Studies 38:3 (2014), 430-45.

Fassin, Didier. “Compassion and Repression: The Moral Economy of Immigration Policies in France." Cultural Anthropology 20:3 (2005), 362-87.

Fauser, Margit. "Transnational Migration - A National Security Risk? Securitization of Migration Policies in Germany, Spain and the United Kingdom.” Reports and Analyses 2:6 (2006), 1-18.

Foucault, Michel. Society Must Be Defended: Lectures at the Collège De France, 1975-76, transalted by David Macey. New York: Picador, 2003.

Foucault, Michel. The Birth of Biopolitics, Lectures at the Collège De France, 1978-79, edited by Michel Senellart. Hampshire and New York: Palgrave MacMillan, 2008.

Foucault, Michel. Histoire de la Sexualité: La Volonté de Savoir. Paris: Gallimard, 1976.

Green, Sarah. "Performing Border in the Aegean." Journal of Cultural Economy 3:2 (2010), 261-78.

Gündoğdu, Ayten. Rightlessness in an Age of Rights: Hannah Arendt and the Contemporary Struggles of Migrants. Oxford: Oxford University Press, 2015.

Häkli, Jouni and Kirsi Pauliina Kallio. “Bodies and Persons: The Politics of Embodied Encounters in Asylum Seeking.” Progress in Human Geography 45:4 (2020), 1-22.

Hardt, Michael and Antonio Negri. Multitude: War and Democracy in the Age of Empire. New York: Penguin Books, 2004.

Hobbes, Thomas. Leviathan. Peterborough: Broadview Press, 2002.

Honig, Bonnie. "Toward an Agonistic Feminism: Hanah Arendt and the Politics of Identity." In Feminists Theorize the Political, edited by Judith Butler and Joan Wallach Scott, 215-35. New York: Routledge, 1992.

Judge, Ruth. Refugee Advocacy and the Biopolitics of Asylum in Britain The Precarious Position of Young Male Asylum Seekers and Refugees. Oxford: Refugee Studies Centre Oxford Department of International Development University of Oxford, 2010.

Kirtsoglou, Elisabeth and Giorgos Tsimouris. "Il était un petit navire": The Refugee Crisis, Neoorientalism, and the Production of Radical Alterity." Journal of Modern Greek Studies 9 (2016), 1-4.

Levy, Karl. "Refugees, Europe, Camps/State of Exception: "Into the Zone” of the European Union and Extraterritorial Processing of Migrants, Refugees and Asylum Seekers.” Refugee Survey Quarterly 29:1 (2010), 92-119.

Mbebe, Achille. "Necropolitics." Public Culture 15:1 (2003), 11-40.

Mbebe, Achille. Necropolitics. Derham and London: Duke University Press, 2019.

Nyers, Peter. "Emergency or Emerging Identities? Refugees and Transformations in World Order." Millennium: Journal of International Studies 28:1 (1999), 1-26.

Nyers, Peter. Rethinking Refugees: Beyond State of Emergency. New York: Routledge, 2006.

Nyers, Peter. Irregular Citizenship, Immigration, and Deportation. New York: Routledge, 2019.

Ongur, Hakan Övünç and Hüseyin Zengin. "Reading Agamben Backwards: Syrian Refugees, Biopolitics and Sovereignty in Turkey.” Social Science Information 58:1 (2019), 103-20. 
Owens, Patricia. "Beyond 'Bare Life': Refugees and the 'Right to Have Rights.” In Refugees in International Relations, edited by A. Betts and G. Loescher, 133-51. Oxford: Oxford University Press, 2011.

Papastergiades, Nikos. "Wog Zombie: The De- and Re-Humanisation of Migrants, from Mad Dogs to Cyborgs." Cultural Studies Review 15:2 (2009), 147-78.

Rozakou, Katerina. "The Biopolitics of Hospitality in Greece: Humanitarianism and the Management of Refugees." American Ethnologist 39:3 (2012), 562-77.

Sassen, Saskia. Globalization and its Discontents: Essays on the New Mobility of People and Money. New York: The New Press, 1999.

Sassen, Saskia. Guests and Aliens. New York: The New Press, 2000.

Sassen, Saskia. "The Repositioning of Citizenship: Emergent Subjects and Spaces for Politics," Berkeley Journal of Sociology 46 (2002), 4-26.

Saunders, Natasha Emilie Georgina and Patrick Hayden. "Solidarity at the Margins: Arendt, Refugees, and the Inclusive Politics of World-Making." In Arendt on Freedom, Liberation, and Revolution, edited by Kei Hiruta, 171-99. Cham: Palgrave Macmillan, 2019.

Tyler, Imogen and Katarzyna Marciniak. Immigrant Protest: Politics, Aesthetics, and Everyday Dissent. New York: SUNY Press, 2014.

Tyler, Imogen and Katarzyna Marciniak. Protesting Citizenship: Migrant Activisms. London: Routledge, 2014.

Zaborowski Rafal and Myria Georgiou. "Gamers Versus Zombies? Visual Mediation of the Citizen/Non-Citizen Encounter in Europe's 'Refugee Crisis.” Popular Communication 17:1 (2019), 1-17.

Zaborowski Rafal and Myria Georgiou. Media Coverage of the "Refugee Crisis": A cross-European Perspective. Stanbourg: Council of Europe, 2016.

Zembylas, Michalinos. "Agamben's Theory of Biopower and Immigrants/Refugees/Asylum Seekers Discourses of Citizenship and the Implications For Curriculum Theorizing." Journal of Curriculum Theorizing 26:2 (2010), 30-45.

Žižek, Slavoj. Die neue Klassenkampf: Die wahren Gründe für Flucht und Terror. Berlin: Ullstein, 2015. 